\title{
Histological study on the effect of garlic extract on induced wound in male rat: Possible role of endogenous stem cells
}

\author{
Mahmoud Reda*, Lamiaa Ibrahim AbdEl Fattah ${ }^{* *}$, Dalia Hussein Helmi, Asmaa \\ Mahmoud Mostafa and Laila Ahmed Rashed ${ }^{\wedge}$ \\ Original \\ Article \\ "Department of General Surgery Misr University for Science and Technology (MUST), Egypt \\ ${ }^{* *}$ Department of Histology Faculty of Medicine, Cairo University, Egypt \\ \#Department of Histology Faculty of Medicine, Beni-Suef University, Egypt \\ 'Department of Biochemistry Faculty of Medicine, Cairo University, Egypt
}

\begin{abstract}
Background and Objectives: Chronic wounds represent a significant health problem. Novel therapeutic approaches to wound healing are required. Garlic (Allium sativum) was considered to exert antioxidant, antibacterial, and anticholesterol activities. Aim of the work: The present work aimed at investigating the possible therapeutic effect of garlic extract (GE) on induced wound in male albino rat. The possible role of endogenous stem cells was also determined.

Materials and Methods: 26 adult male albino rats were divided into Group I (Control group): 6 rats not exposed to wound induction.Group II (Wounded group): 10 rats were exposed to wound induction and subdivided into subgroups IIa and IIb, 5 animals each, were sacrificed 2 and 3 weeks following wound induction. Group III (Wounded and GE treated group): 10 rats were exposed to wound induction and subdivided as in group II. $0.5 \mathrm{ml}$ of 1\% GE was locally applied following wound induction. Skin specimens (including the wound and a margin of normal skin around) were subjected to histological, immunohistochemical, morphometric and statistical studies.

Results: Morphological changes, indicating inflammation and degeneration, were found in wounded rats. These changes regressed remarkably by the use of GE. The regression of apoptosis was confirmed by caspase 3 immunostaining and the activation of stem cells was proved by CD44 immunostaining.

Conclusions: GE therapeutic effect was proved to be related to both caspase 3 pathway inactivation and MSC migration activation. GE was suggested to be applied in appropriate concentrations in the preparation of pharmaceutical products to be used safely on epithelial cells in wound care.
\end{abstract}

Key Words: Allicin, Garlic extract, MSCs, wound

Revised: 4 March 2018 Accepted: 22 February 2018

Corresponding Author: Mahmoud Reda, Departments of General Surgery Misr University for Science and Technology (MUST), Egypt, Tel.: +2/0123955078, E-mail: mreda1@yahoo.com

ISSN: 2536-9172, Vol.1, No.2

\section{INTRODUCTION}

The epidermis functions in skin as first defense line or barrier against environmental impacts, resting on extracellular matrix $(\mathrm{ECM})$ of the dermis ${ }^{[1]}$. Clinical approaches to the treatment of wounds are numerous, but individually often do not provide an ideal solution. Problems with local administration of agents with low efficacy are the main drawbacks ${ }^{[2]}$. Chronic wounds represent a significant health problem. Novel therapeutic approaches to wound healing are required ${ }^{[3]}$. Garlic (Allium sativum) was considered to exert antioxidant and antibacterial activities ${ }^{[4]}$.

Self-renewal and multipotency are the key hallmarks of stem cells, permitting them to act as the fundamental units maintaining growth, homeostasis and repair of many tissues. These two key features establish stem cells as the most promising tool for regenerative medicine. Among the different types of stem cells, mesenchymal stem cells (MSCs) or multipotent mesenchymal stromal cells are considered as a potential tool to treat degenerative diseases ${ }^{[5]}$. A recent study investigated whether endothelial progenitor cells induce favourable effects on cutaneous incisional wound healing in mice $\mathrm{e}^{[6]}$.

The present work aimed at investigating the possible therapeutic effect of garlic extract (GE) on induced wound in male albino rat. The possible role of endogenous stem cells was also determined.

\section{MATERIALS AND METHODS}

\section{Drugs and chemicals}

Garlic Extract (GE) was prepared by buying the garlic from a local vegetable market. The garlic bulbs were peeled and ground to form a paste in $1 \mathrm{~g}$ quantity. At the 
Biochemistry Department, Faculty of Medicine, Cairo University the paste was dissolved in $100 \mathrm{ml}$ distilled water in a sterile tube. The solution was centrifuged at $6000 \mathrm{rpm}$ for 20 minutes at room temperature. The pellet was discarded and supernatant was diluted 10 times with KY gel to get $1 \%$ of garlic extract. The concentration used is based on a previous study ${ }^{[7]}$. Allicin was considered the main active constituent of $\mathrm{GE}^{[8]}$.

\section{Animals}

Twenty six adult male albino rats each weighing $200 \mathrm{~g}$ were used in the present study. The animals were housed in the Animal House of Histology Department, Faculty of Medicine, Cairo University under good hygienic conditions of air, temperature, fed ad libitum and allowed for free water supply. The animals were treated according to the ethical guidelines of Cairo University. The animals were divided into five groups, kept in separate cages.

\section{Group I (Control group): six rats subdivided into:}

Subgroup Ia: Three rats received $0.5 \mathrm{ml} \mathrm{KY}$ gel by local application on the skin of the back 6 days/week, one rat for 2 and the other for 3 weeks.

Subgroup Ib: Three rats received $0.5 \mathrm{ml} 1 \%$ GE by local application on the skin of the back 6 days/week, one for 2 and the other for 3 weeks.

\section{Group II (Wounded group):}

Ten rats were exposed to wound induction. Wound induction was performed by anaesthetizing the rats using ketamine hydrochloride (Ketalar, (Parke Davis Barcelona, Spain) $(35 \mathrm{mg} / \mathrm{kg})$, injected into the gluteus maximus muscle of the animal. The hair was shaved on the middle part of the back, using aseptic techniques, a $3 \mathrm{~cm}$ longitudinal skin incision was made using a sterile scalpel ${ }^{[9]}$. Betadine was applied to the wound site and rinsing with normal saline was performed at the site of injury daily. The animals were subdivided into 2 subgroups according to time of sacrifice.

Subgroup IIa: 5 animals were sacrificed 2 weeks following wound induction.

Subgroup IIb: 5 animals were sacrificed 3 weeks following wound induction.

\section{Group III (Wounded and GE treated group):}

Ten rats were exposed to wound induction as in group II. $0.5 \mathrm{ml}$ of $1 \%$ GE was locally applied on the wound and on the surrounding skin margins for 6 days/week at an interval of $24 \mathrm{~h}$ following wound induction. The animals were subdivided into 2 subgroups according to time of sacrifice:

Subgroup IIIa: 5 animals were sacrificed 2 weeks following wound induction and GE application.
Subgroup IIIb: 5 animals were sacrificed 3 weeks following wound induction and GE application.

The animals belonging to control and corresponding experimental groups were sacrificed by ether inhalation. Skin specimens were obtained from the back (including the wound and a margin of normal skin around) and fixed in $10 \%$ formol saline for 48 hours. Paraffin blocks were prepared and $5 \mu \mathrm{m}$ thick sections were subjected to the following studies:

\section{Histological Study:}

Hematoxylin and eosin ${ }^{[10]}$

\section{Immunohistochemical Study:}

1. Caspase 3 immunostaining ${ }^{[1]}$ the marker for apoptosis. $0.1 \mathrm{ml}$ diluted primary antibody $(\mathrm{Ab})$ (Caspase 3 3015100- Ab) (Biovision, Milpitas Boulevard, Milpitas, CA USA) stored at $28-{ }^{\circ} \mathrm{C}$.

2. $\mathrm{CD} 44 \mathrm{Ab}$ to detect the endogenous $\mathrm{MSCs}^{[12]} .0 .1 \mathrm{ml}$ prediluted rabbit monoclonal 1ry Ab (IW-PA1021) (IHC World, Ellicott City, USA) stored at $28-{ }^{\circ} \mathrm{C}$. The primary $\mathrm{Ab}$ was applied to the sections for 60 minutes at RT and the +ve tissue control was a specimen of human tonsil for both markers. Caspase 3 showed cytoplasmic reaction and CD44 +ve cells showed membranous reaction. The -ve tissue control was processed in the same way, but omitting the step of 1ry Ab.

\section{Morphometric Study}

Using Leica Qwin 500 LTD (Cambridge UK) computer assisted image analyzer, assessment of the distance between the discontinuous margins of epidermis and epidermal thickness were performed in H\&E stained sections. The measurements were done in 10 low power fields (LPF) in control and experimental groups using interactive measurements menu. In addition, the area $\%$ of Caspase 3 +ve cells and that of CD44 +ve cells were recorded in immunostained sections. The measurements were done in 10 high power fields (HPF) in control and experimental groups using binary mode.

\section{Statistical analysis}

Quantitative data were summarized as means and standard deviations (SD) and compared using one-way analysis-of-variance (ANOVA). P-values $<0.05$ were considered statistically significant. Calculations were made on social package of statistical study software version $16^{[13]}$.

\section{RESULTS}

None of the animals died during the experiment. The following results were recorded by examination of various sections of the skin belonging to control and experimental groups, which were subjected to 
histological, immunohistochemical and morphometric studies.

\section{A) Histological Results:}

\section{Haematoxylin and Eosin (H\&E) Stained}

Sections:

\section{Group I (Control Group):}

Skin sections of all control rats demonstrated epidermis, dermis and sebaceous glands related to hair follicles (Fig 1a). Close observation revealed basal, spiny, granular and horny layers forming the epidermis. Hair follicles appeared as invaginations of epidermis into the dermis and were lined by epidermal cells. Vacuolated sebocytes and basal cells were seen lining the secretory part of sebaceous glands. (Fig 1b). Keratinocytes of basal and spiny layers exhibit pale nuclei, while granular layer is characterized by dark basophilic cytoplasm of the keratinocytes. Flattened non-nucleated keratinized squames were seen in horny layer (Fig 1c).

\section{Group II (Wounded Group):}

Subgroup IIa (sacrificed 2 weeks following wound induction)

In this subgroup, separation of the wound edges and epidermal thickening was remarkable at one side. Diffuse eosinophilic homogenous material was seen extending among the other side. Detached fibers of the horny layer and impacted keratin between the epidermal layers were noticed (Fig 2a). Close observation demonstrated nuclear margination in multiple vacuolated epidermal cells and separation of the underlying C.T fibers. Some blood vessels, multiple extravasated RBCs and eosinophilic homogeneous material were observed among the dermis (Fig 2b).

Subgroup IIb (sacrificed 3 weeks following wound induction):

Less obvious separation of the epidermal edges of the wound, less thickening of the epidermis and less eosinophilic homogenous material were detected in this subgroup compared to subgroup IIa. Occasional congested blood vessels were found (Fig 3a). Close observation revealed cellular debris in occasional wide vacuolated areas and detached small superficial parts of the epidermis (Fig 3b).

\section{Group III (Wounded and GE Treated Group)}

Subgroup IIIa (sacrificed 2 weeks following wound induction and GE application)
Compared to subgroup IIa, in this subgroup, localized separation of epidermal edges and localized homogeneous acidophilic material collected in the epidermis were seen. In addition deeply acidophilic material and keratin whorls were observed at the surface. Epidermal thickening was seen on one side of the wound. Some hair follicles were seen deep in the dermis and separation of some C.T fibers was noticed (Fig 4a). Close observation recruited discontinuity of granular and horny cell layers and occasional keratin whorls were impacted between the discontinuous edges. Few vacuolated cells with nuclear margination and occasional localized vacuolated areas containing cellular debris were seen (Fig 4b). The follicles noticed deep in the dermis were lined by multiple layers of cells and the secretory part of the related sebaceous glands was lined by sebocytes exhibiting vacuolated cytoplasm (Fig 4c).

Subgroup IIIb (sacrificed 3 weeks following wound induction and GE application)

Small detached parts of horny layer and focal separation of epidermal edges were found in this subgroup, where the horny layer was seen covering most of the surface of the epidermis. Some follicles with related sebaceous glands, microfollicles and multiple deep follicles in the dermis were detected (Fig 5a). Close observation revealed few epidermal cells demonstrating nuclear margination among normally appearing epidermal cells (Fig 5b). Some microfollicles lined by two layers of flattened cells and exhibiting few keratinized cells in their centers were found (Fig 6a). Some of the deeper follicles showed the medulla of hair, some others exhibited a single peripheral layer of vacuolated cells and occasional ones demonstrated medulla, cortex of hair, internal root and external root sheaths. In addition, congested blood vessels were noticed (Fig 6b) compared to subgroup IIb.

\section{B)Immunohistochemical Results:}

\section{Caspase3 Immunostained sections:}

\section{Control Group:}

Sections in the skin of control rats showed few Caspase 3 positive immunostained cells. The + ve cells were seen in the superficial layers of the epidermis (Fig $7 a)$.

\section{Group II (Wounded Group):}

Sections in the skin of rats belonging to subgroups IIa and IIb showed multiple +ve epidermal cells and multiple + ve cells extending down among the dermis The multiplicity of +ve cells was less apparent in subgroup IIb compared to subgroup IIa (Figs 7b and 7c) 


\section{Group III (Wounded and GE Treated Group):}

Sections in the skin of rats belonging to subgroup IIIa showed some +ve epidermal cells (Fig 8a). While in subgroup IIIb, few +ve cells were found among the epidermis (Fig 8b). In this group, a negative reaction was obvious in the dermis and the multiplicity of $+v e$ cells in the epidermis was less apparent compared to the previous subgroups.

\section{CD44 Immunostained sections:}

\section{Control Group:}

Sections in the skin of control rats showed negative CD44 immunostaining among the epidermis, hair follicles and related sebaceous glands in the dermis (Fig 9a).

\section{Group II (Wounded Group):}

Sections in the skin of rats in subgroup IIa demonstrated some CD44+ve spindle cells in the epidermis and multiple +ve spindle cells in the dermis at the wound margins (Fig 9b). While in subgroup IIb, observation revealed some +ve spindle cells in the epidermis and dermis at the wound margins (Fig 9c).

\section{Group III (Wounded and GE Treated Group):}

Sections in the skin of rats in subgroup IIIa demonstrated multiple +ve spindle cells in the epidermis and dermis at the wound margins (Fig 10a). In addition, multiple +ve spindle cells were evident in few hair follicles, in the dermis and hypodermis (Fig 10b) compared to subgroup IIa.

On the other hand, sections in the skin of rats in subgroup IIIb showed few +ve spindle cells in the epidermis and dermis at the wound margins (Fig 11a). In addition, multiple +ve spindle cells were recruited in some hair follicles, while some +ve spindle cells were found in the dermis and hypodermis (Fig 11b) compared to subgroup IIb.

Table 1: Mean \pm standard deviation (SD) of the distance between (bet) epidermal margins (em), thickness (th) of epidermis (ep) in control and experimental groups

\begin{tabular}{|l|c|c|}
\hline $\begin{array}{l}\text { Groups and } \\
\text { Subgroups }\end{array}$ & Distance bet em & th of ep \\
\hline Control group & & $34.72 \pm 3.38$ \\
\hline $\begin{array}{l}\text { Group II (Wounded group): } \\
\text { Subgroup IIa }\end{array}$ & $39.98 \pm 3.31 \#$ & $79.72 \pm 13.25 \$$ \\
\hline Subgroup IIb & $28.99 \pm 5.32 \#$ & $44.21 \pm 9.18$ \\
\hline $\begin{array}{l}\text { GroupIII (Wounded GE treated group): } \\
\text { Subgroup IIIa }\end{array}$ & $15.98 \pm 3.31^{\circ}$ & $48.92 \pm 10.49$ \\
\hline Subgroup IIIb & $5.99 \pm 0.32$ & $36.09 \pm 5.30$ \\
\hline
\end{tabular}

\# significant compared to subgroups IIIa and IIIb

${ }^{\circ}$ significant compared to subgroup IIIb

\$ significant compared to control and subgroup IIIb

Table 2: Mean \pm standard deviation (SD) of the area $\%$ of caspase 3 +ve cells and area $\%$ of CD44 +ve cells in control and experimental groups

\begin{tabular}{|c|c|c|}
\hline $\begin{array}{c}\text { Groups and } \\
\text { Subgroups }\end{array}$ & Area \% caspase3 +ve cells & Area\% of CD44 +ve cells \\
\hline Control group & $0.56 \pm 0.07$ & $3.89 \pm 0.62$ \\
\hline $\begin{array}{c}\text { Group II (Wounded group): } \\
\text { Subgroup IIa }\end{array}$ & $10.21 \pm 0.99 \#$ & $3.29 \pm 0.19$ \\
\hline Subgroup IIb & $8.22 \pm 1.19 \#$ & $11.38 \pm 1.46^{*}$ \\
\hline $\begin{array}{c}\text { GroupIII (Wounded treated group): } \\
\text { Subgroup IIIa }\end{array}$ & $1.66 \pm 0.12$ & $8.99 \pm 2.11^{*}$ \\
\hline Subgroup IIIb & $0.81 \pm 0.03$ & \\
\hline
\end{tabular}

\# significant compared to control, subgroups IIIa, IIIb

* significant compared to subgroups IIa, IIb 



Fig 1: Photomicrographs of sections in the skin of group I showing (H\&E,). a: epidermis (E), dermis (D), sebaceous glands (arrowhead) related to hair follicles (arrow) (x 100). b: basal (b), spiny (s) granular (g) and horny (h) layers. Vacuolated sebocytes $\left(^{*}\right)$ and basal cells (arrowhead) are seen lining the secretory part of sebaceous glands. Epidermal cells are seen lining the hair follicle (arrow) (x 200). c: pale nuclei $(\mathrm{N})$ of basal and spiny layers, dark basophilic cytoplasm of granular $(\mathrm{g})$ and flattened non-nucleated keratinized squames in horny (h) layer

(x 400). 

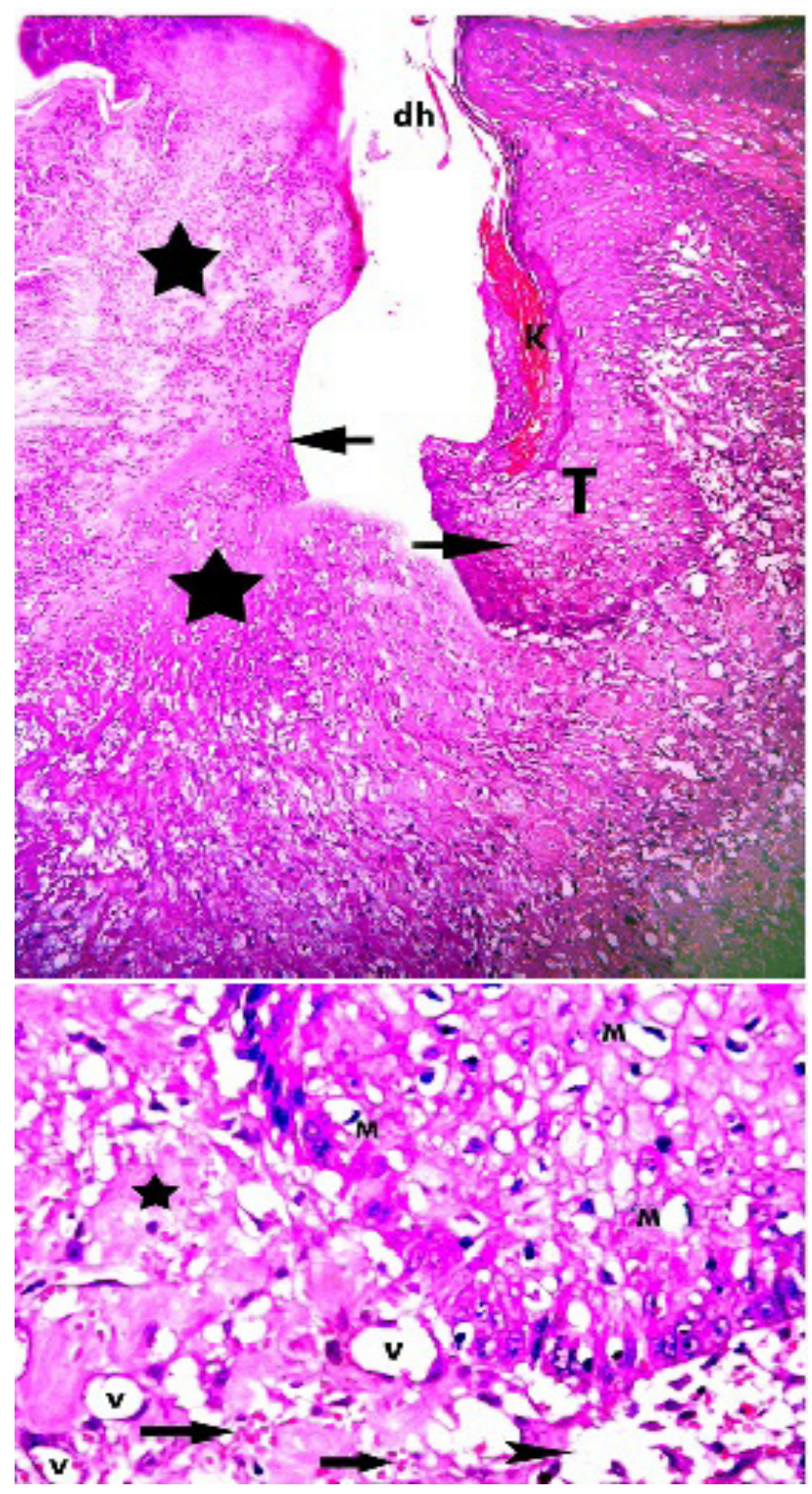

Fig 2: Photomicrographs of sections in the skin of subgroup IIa showing (H\&E,). a: showing separation of wound edges (arrows). The epidermis appear thickened at one side (T) and diffuse eosinophilic homogenous material $(*)$ is seen extending among the other side. Note detached fibers of horny layer $(\mathrm{dh})$ and impacted keratin (K) (x 100). b: nuclear margination (M) in vacuolated epidermal cells and separation of the underlying C.T fibers (arrowhead). Note some blood vessels (v), multiple extravasated RBCs (arrow) and eosinophilic homogeneous material $(*)$ among the dermis

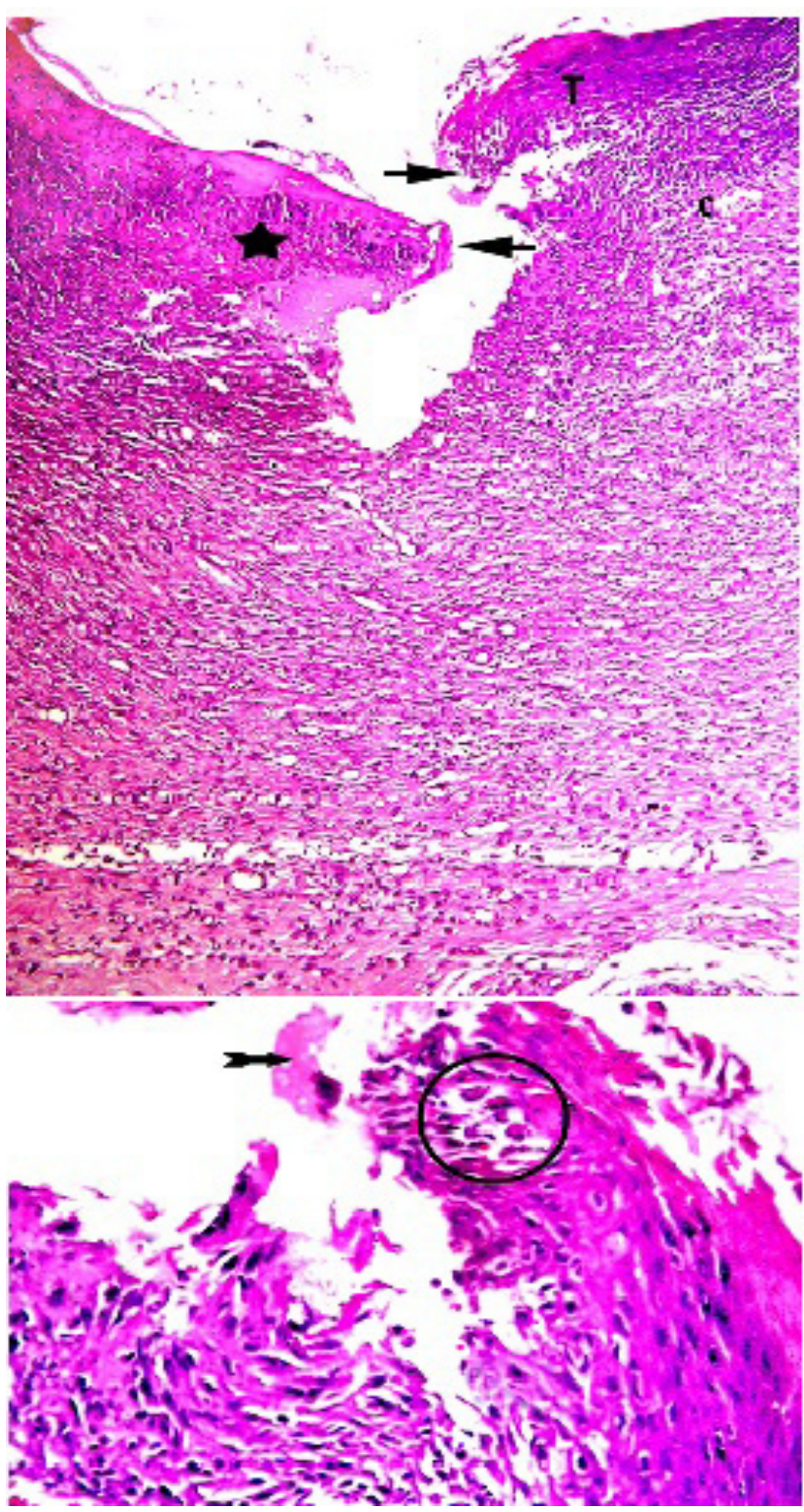

Fig 3: Photomicrographs of sections in the skin of subgroup IIb showing (H\&E,). a: less obvious separation of epidermal edges (arrows), less thickening of epidermis (T) and less eosinophilic homogenous material $(*)$. Note a congested blood vessel (c) (x 100). b: cellular debris in a wide vacuolated area (circle) and a detached small superficial part of the epidermis (bifid arrow)

(x 400). 


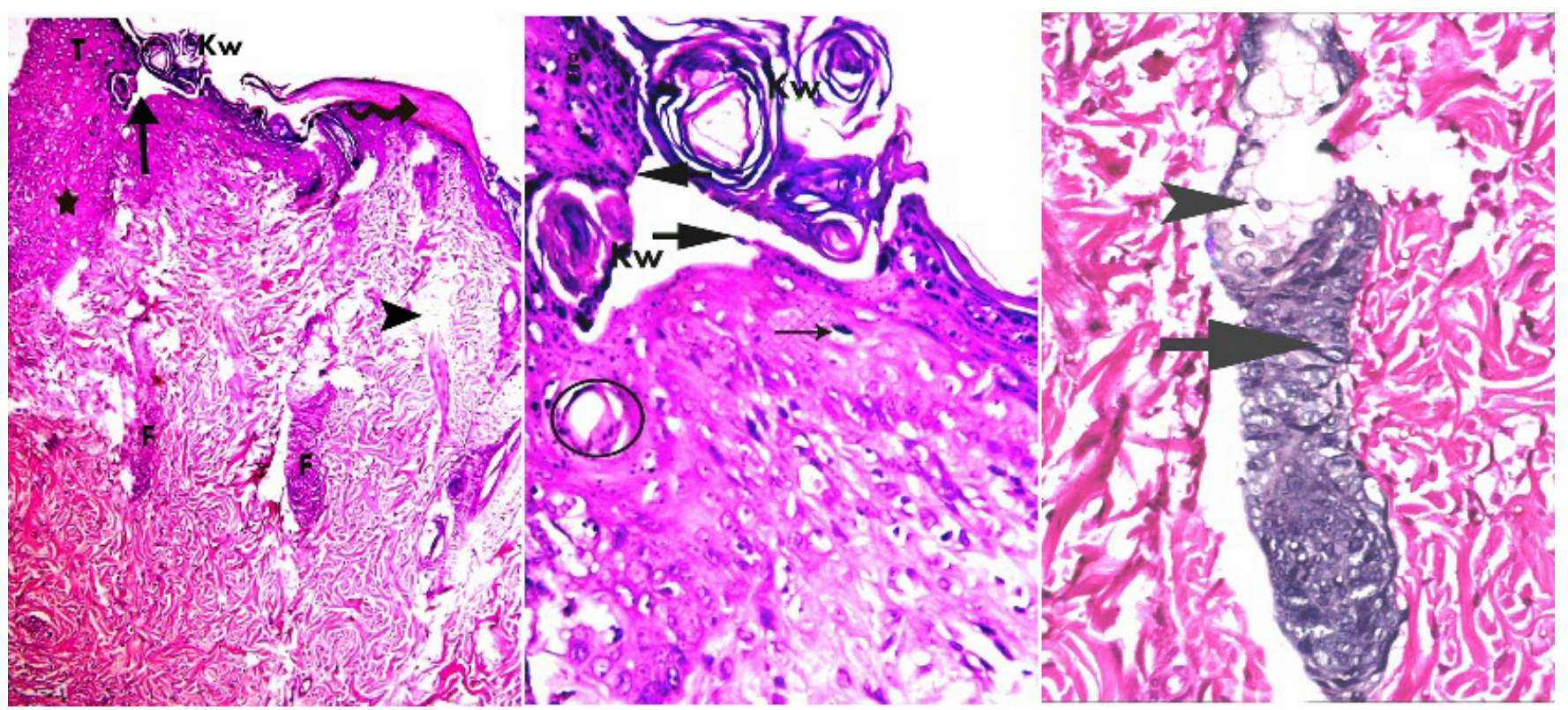

Fig 4: Photomicrographs of sections in the skin of subgroup IIIa showing (H\&E,). a: localized separation of epidermal edges (arrow), localized homogeneous acidophilic material $(*)$, deeply acidophilic material (curved arrow) and keratin whorls $(\mathrm{Kw})$ at the surface. Epidermal thickening $(\mathrm{T})$ is seen on one side of the wound. Note some hair follicles $(\mathrm{F})$ and separation of C.T fibers in the dermis (arrowhead) (x 100). b: discontinuity of granular (g) and horny cell layers (arrows), one of the keratin whorls (Kw) is impacted between the edges. Few vacuolated cells with nuclear margination (thin arrow) and a localized vacuolated area containing cellular debris (circle) are seen (x 400). c: showing a follicle lined by multiple layers of cells (arrow) and a related sebaceous gland lined by sebocytes exhibiting vacuolated cytoplasm (arrowhead)

(x 400).

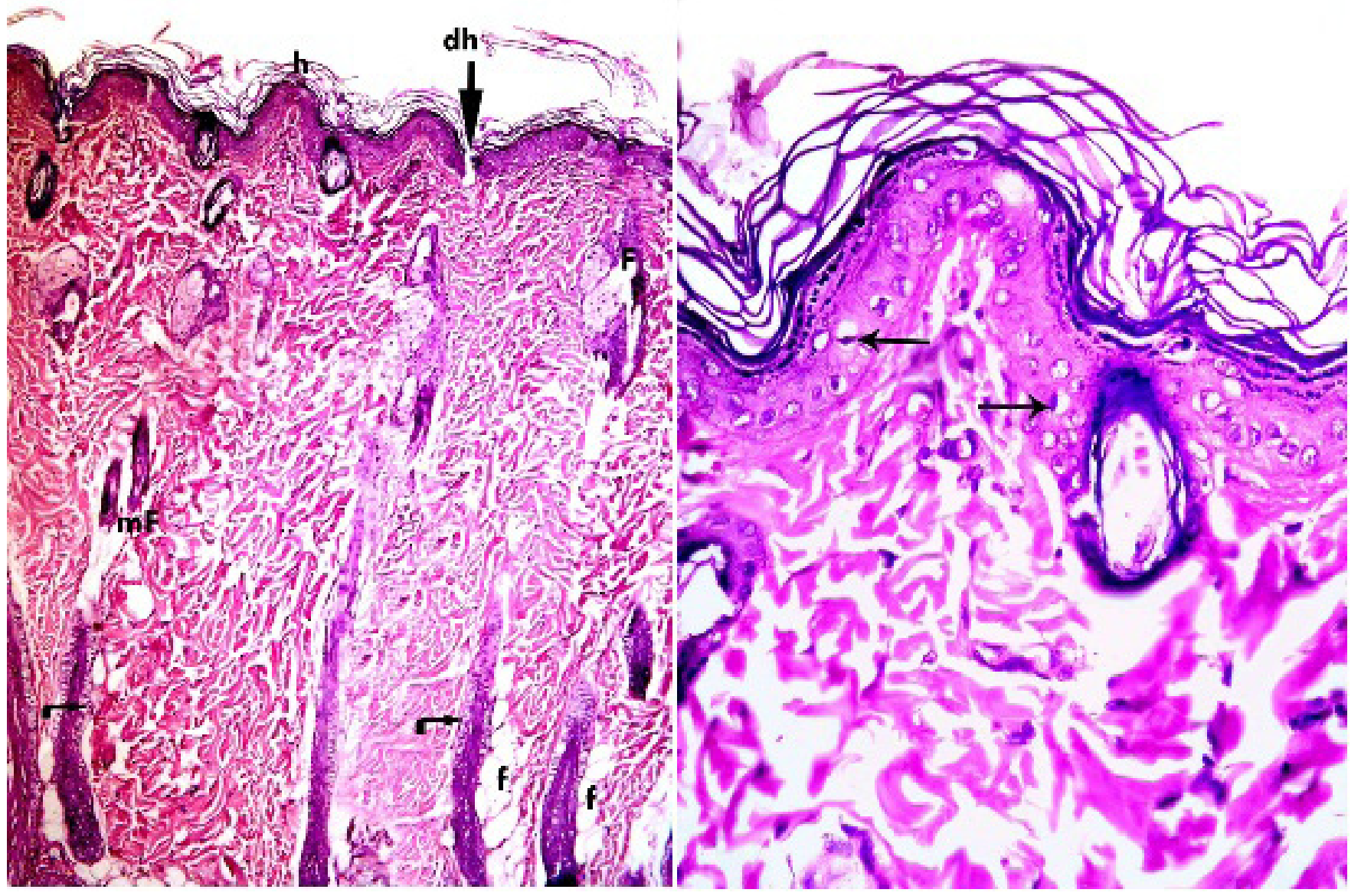

Fig 5: Photomicrographs of sections in the skin of subgroup IIIb showing (H\&E,). a: small detached part of horny layer (dh), focal separation of epidermal edges (arrow), the horny layer (h) covers most of the surface of the epidermis, follicles with sebaceous glands (F), microfollicles $(\mathrm{mF})$ and multiple deep follicles (angled arrows). Note fat cells (f) (x 100). b: two epidermal cells with nuclear margination (thin arrows) among normally appearing epidermal cells

(x 400). 


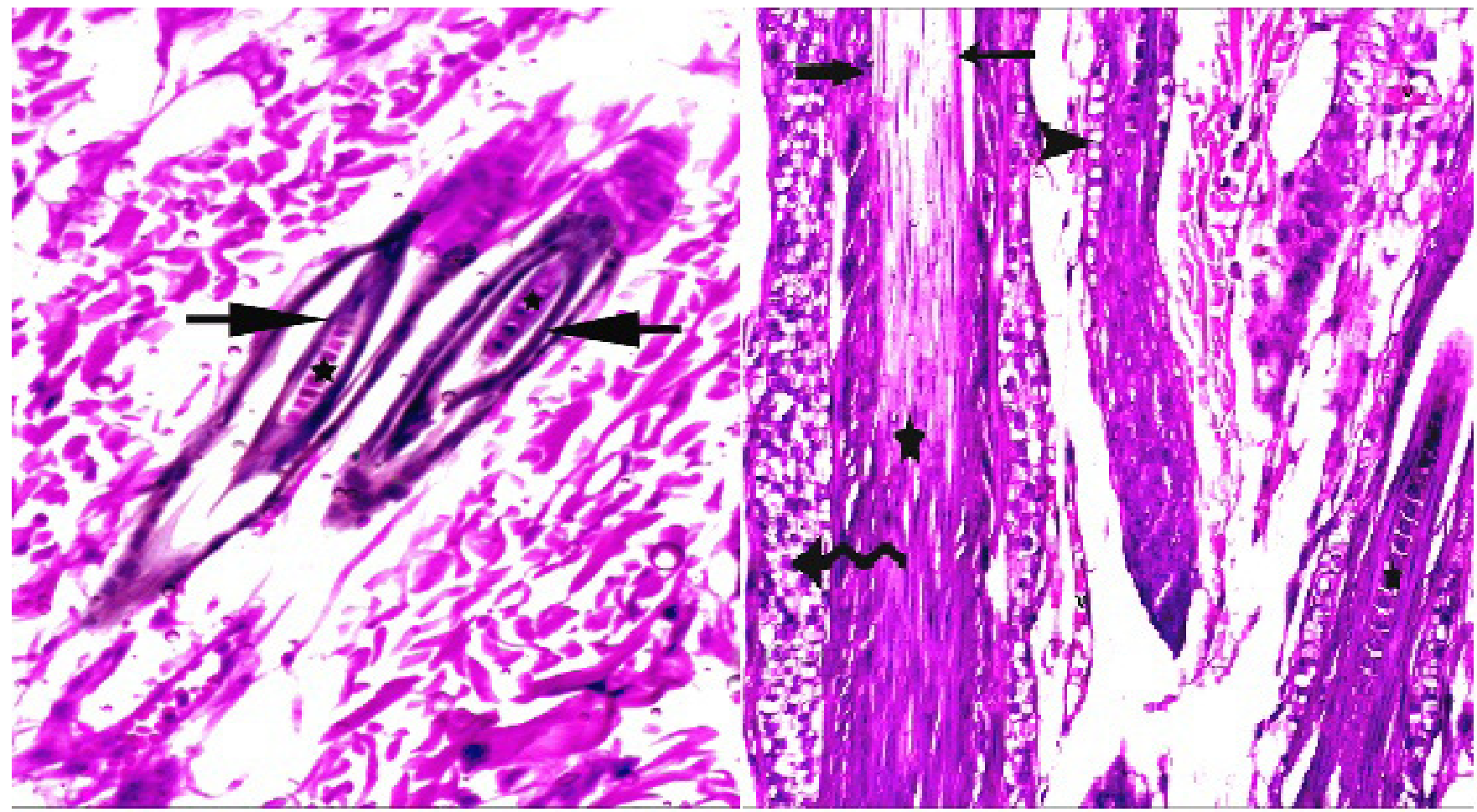

Fig 6: Photomicrographs of sections in the skin of subgroup IIIb showing (H\&E, x400). a: two microfollicles lined by two layers of flattened cells (arrows) and exhibiting few keratinized cells in their centers $\left(^{*}\right)$. b: to the right a follicle exhibiting the medulla of a developing hair $(*)$, another one exhibiting a single peripheral layer of vacuolated cells (arrowhead) and a 3rd one exhibiting medulla $(*)$, cortex (thin arrow) of hair, internal root (thick arrow) and external root (wavy arrow) sheaths. Note congested blood vessels (v).

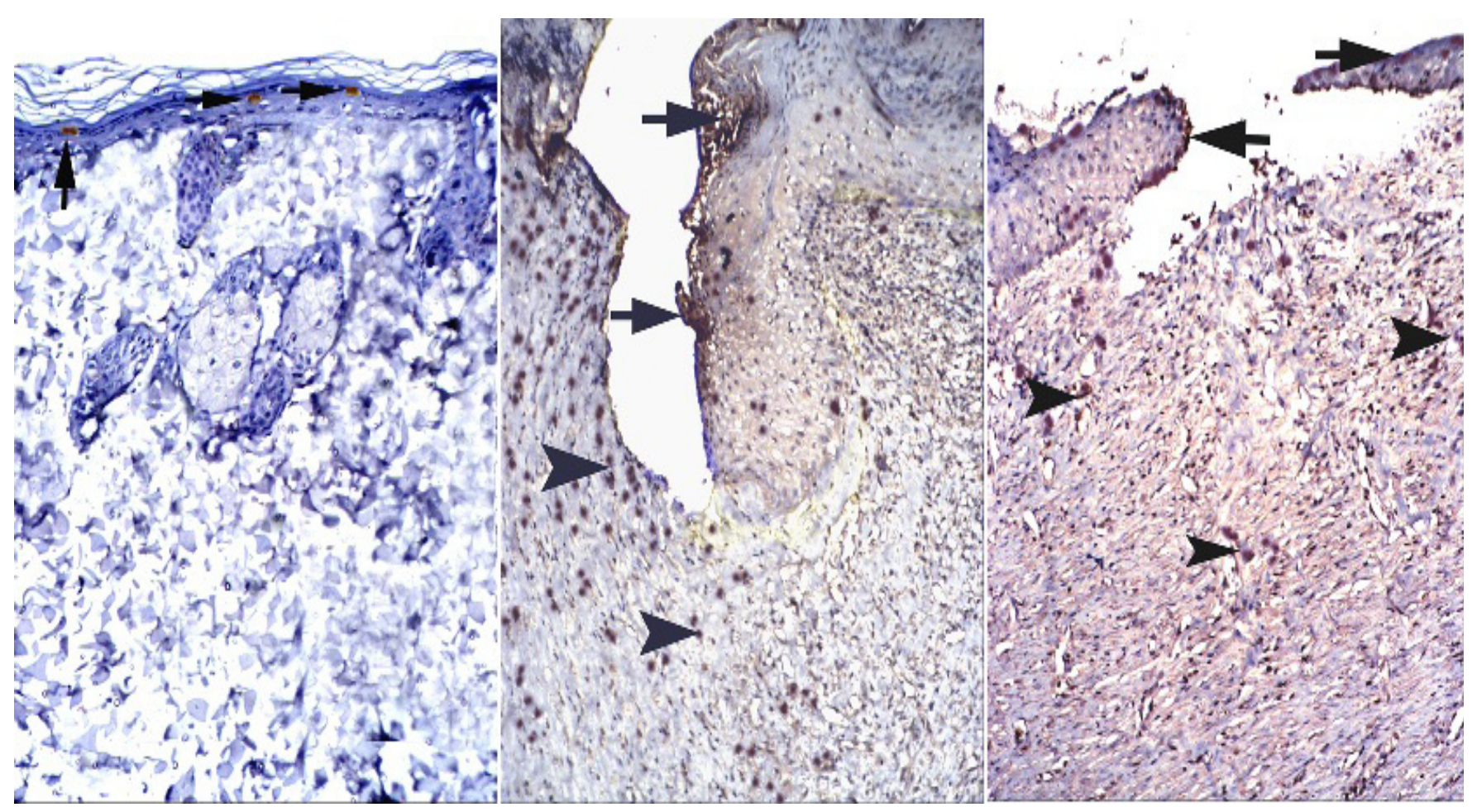

Fig 7: Photomicrographs of sections in the skin of (caspase3 immunostaining,x100). a: group I showing few Caspase 3 +ve immunostained cells (arrows) in the superficial layers of the epidermis. b: subgroup IIa showing multiple +ve epidermal cells (arrows) and multiple +ve cells extending down among the dermis (arrowheads). c: subgroup IIb showing multiple +ve cells among the epidermis (arrows) and multiple + ve cells extending down among the dermis (arrowheads). 


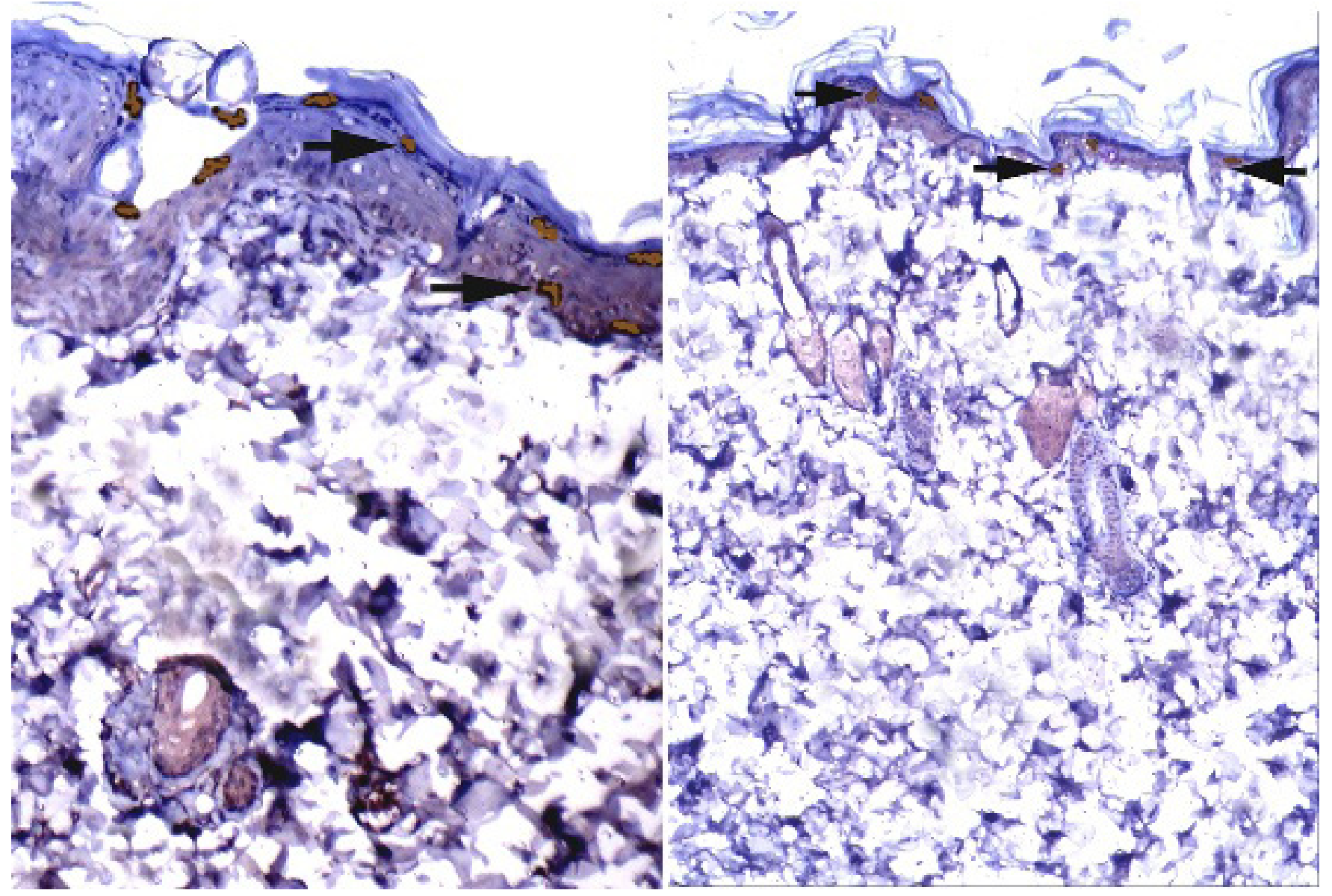

Fig 8: Photomicrographs of sections in the skin of (caspase 3 immunostaining,x100). a: subgroup IIIa showing some +ve cells among the epidermis (arrows). b: subgroup IIIb showing few +ve cells among the epidermis (arrows).

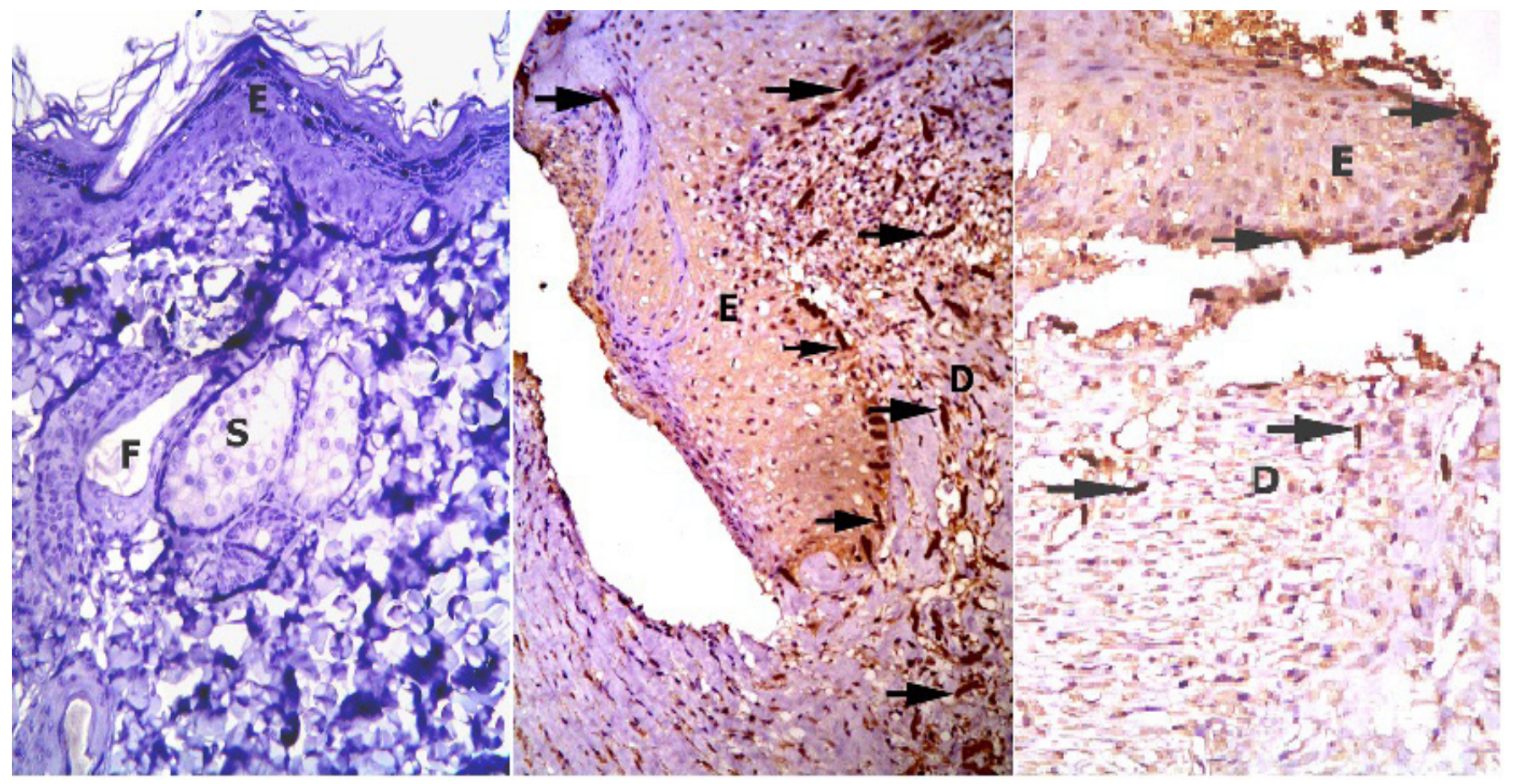

Fig 9: Photomicrographs of sections in the skin of (CD44 immunostaining, x200). a: group I showing negative CD44 immunostaining among the epidermis (E), hair follicles (F) and sebaceous glands (S) in the dermis. b: subgroup IIa showing some +ve spindle cells (arrows) in the epidermis (E) and multiple +ve spindle cells (arrows) in the dermis (D) at the wound margin. c: subgroup IIb showing some +ve spindle cells (arrows) in the epidermis (E) and dermis (D) at the wound margin 


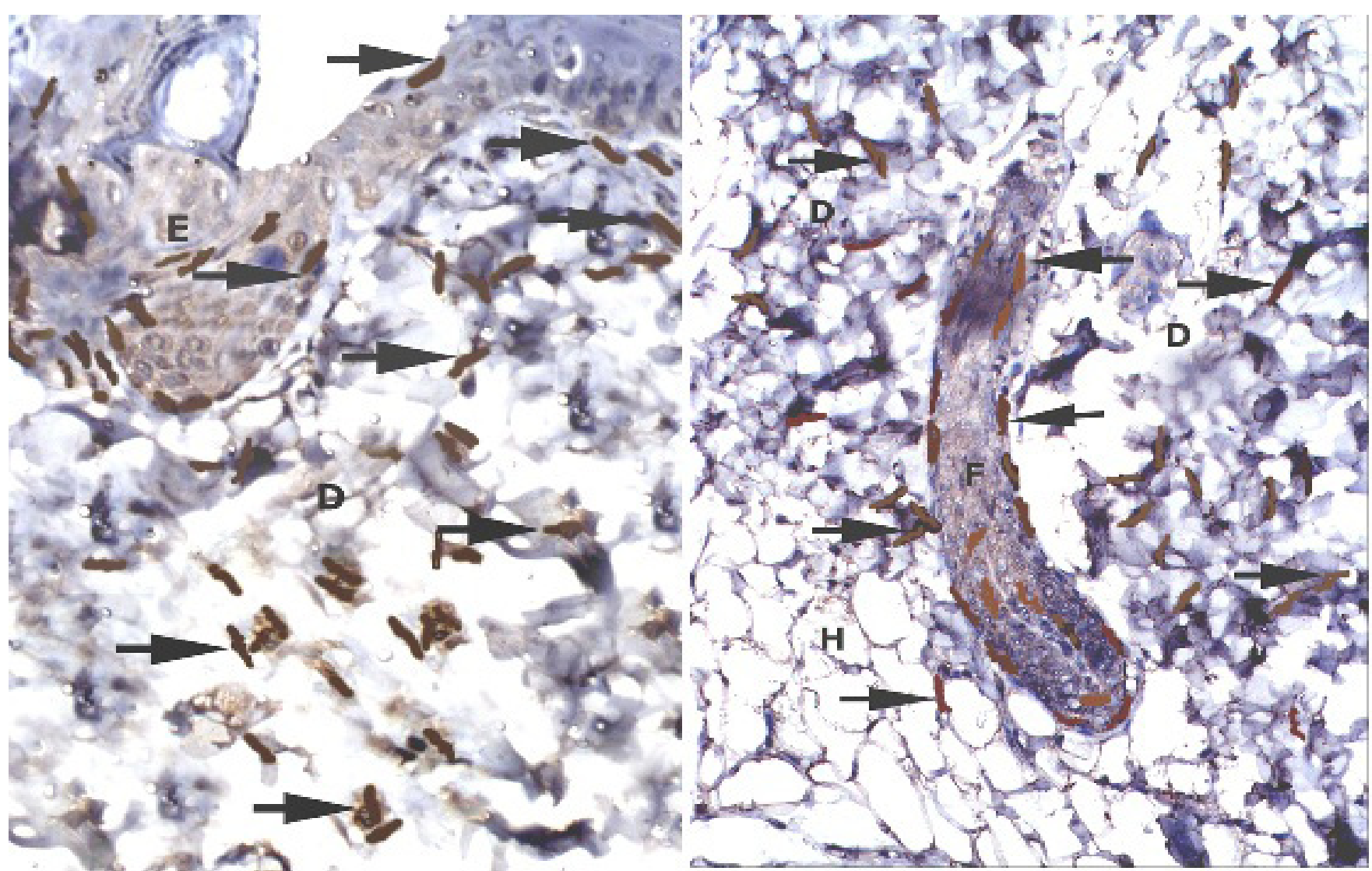

Fig 10: Photomicrographs of sections in the skin of subgroup IIIa showing (CD44 immunostaining, x200). a: multiple +ve spindle cells (arrows) in the epidermis (E) and dermis (D) at the wound margins. b: multiple +ve spindle cells (arrows) in a hair follicle (F), in the dermis (D) and hypodermis $(\mathrm{H})$.
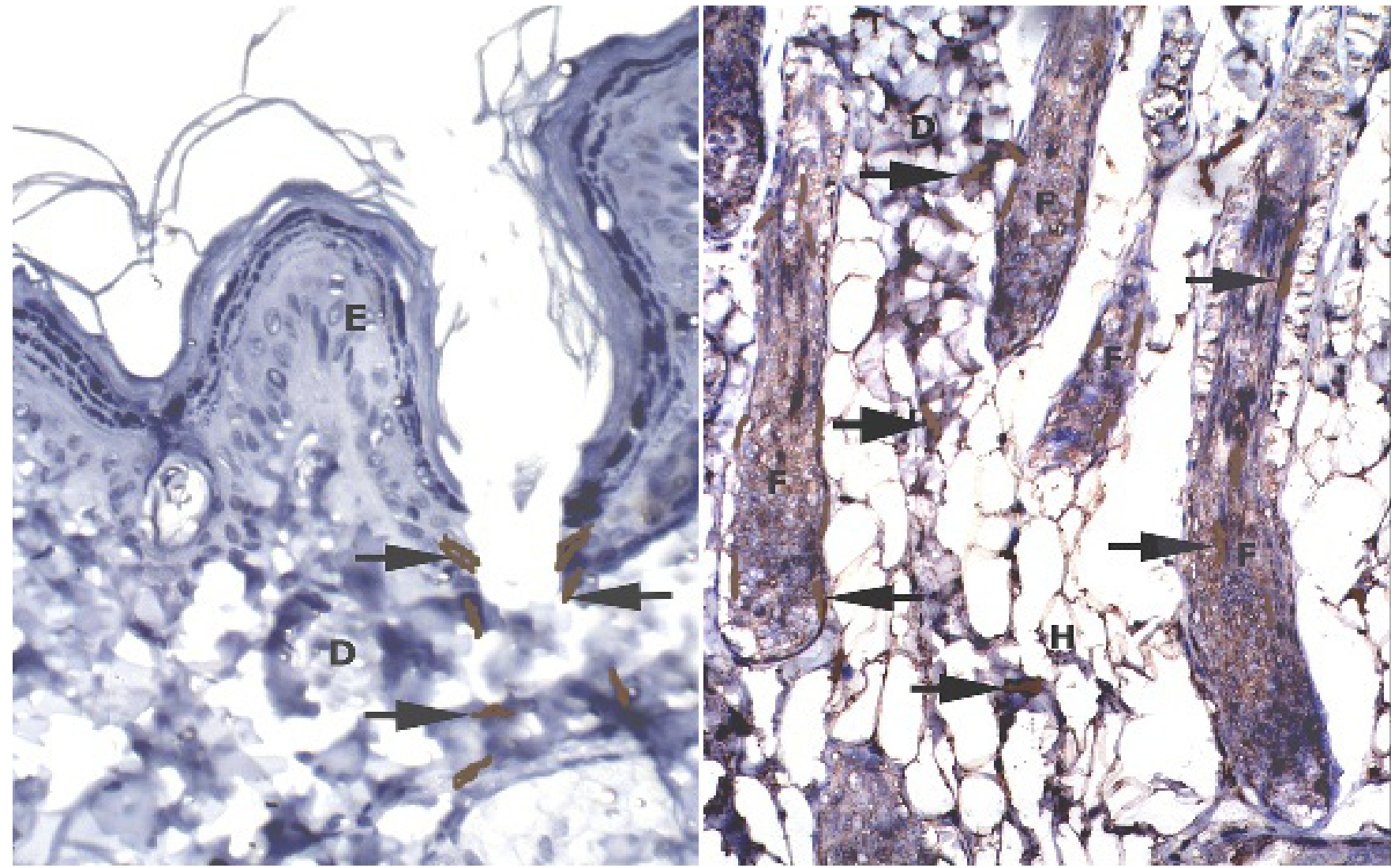

Fig 11: Photomicrographs of sections in the skin of subgroup IIIb showing (CD44 immunostaining, x200). a: few +ve spindle cells (arrows) in the epidermis (E) and dermis (D) at the wound margins. b: multiple +ve spindle cells (arrows) in hair follicles (F) and some $+v e$ spindle cells (arrows) in the dermis (D) and hypodermis (H). 


\section{DISCUSSION}

The current study demonstrated ameliorating effect of garlic extract (GE) on the healing of induced wound in non-diabetic and diabetic rats. This was evidenced by histological, immunohistochemical, and morphometric studies. Animal models were reported to be an efficient method to study wound healing, but often lack correlation with human acute wound healing. Human wound models can be created using sharp instruments ${ }^{[14]}$. Wounds are major concerns for the medical staff and seriously reduce the quality of life of the patient. Furthermore, skin wound is a public health problem with high cost and ineffective treatment ${ }^{[15]}$. Thus, the attempt to quickly close the skin lesions with ideal functional results would be the goal of clinical treatment ${ }^{[16]}$.

In subgroup IIa (Non-diabetic wounded subgroup sacrificed 2 weeks following wound induction), separation of the wound edges, detached fibers of the horny layer and impacted keratin between the epidermal layers were observed. In agreement, it was stated that, within the 2 nd week following experimental wound induction skin defects may be still extensive ${ }^{[17]}$. It was also postulated that, the treatment and care of surgical wounds restricted only to supportive care is associated with acute hypoxia. The latter condition is induced by the clotting of dermal blood vessels during the wounding of skin, which is a major stress factor that leads to the re-programming of basal keratinocytes to initiate re-epithelialization. The laterally migrating keratinocytes secrete extracellular heat shock protein 90 that engages cellular receptors and works as an autocrine factor to stimulate keratinocyte migration (re-epithelialization). Hypoxia-triggered extracellular heat shock protein 90 alpha acts as the master regulator of initial skin wound healing ${ }^{[18]}$.

In addition, in subgroup IIa epidermal thickening at one side and diffuse eosinophilic homogenous material extending among the other side were observed. Nuclear margination in multiple vacuolated epidermal cells was noticed. These changes indicated limited inflammatory and degenerative changes at the wound site. Concomitantly, it was mentioned that the progressive interaction between microbial species and the host is an interactive process that helps evolving an acute-phase infection ${ }^{[19]}$. It was recorded that by the end of the $1^{\text {st }}$ week following experimental wound induction, necrosis and inflammatory cells were extending to the subcutaneous layer. It was also commented that absence of hair follicles and skin glands in addition to disorganized dermal-epidermal layers were found by the end of the $2^{\text {nd }}$ week following experimental wound induction ${ }^{[17]}$.

In subgroup IIa, separation of the underlying connective tissue (C.T) fibers, some blood vessels, multiple extravasated RBCs and eosinophilic homogeneous material were obvious among the dermis. These changes pointed to the formation of granulation tissue. Going with the previous results, it was confirmed that the angiogenic process, thus stimulates cellular motility and mitosis in endothelium and leads to the formation of new capillaries ${ }^{[20]}$.

In subgroup IIb (Non-diabetic wounded subgroup sacrificed 3 weeks following wound induction), less obvious separation of the epidermal edges of the wound, less thickening of the epidermis and less eosinophilic homogenous material, cellular debris in occasional wide vacuolated areas, detached small superficial parts of the epidermis and occasional congested blood vessels were found. These changes indicated progressive wound healing corresponding to longer duration following wound induction in the absence of infection. In agreement, it was postulated that angiogenesis and matrix remodeling developing in wound healing are promoted by activation of cell cycle and cell proliferation executed in a timely and orderly manner ${ }^{[21]}$. In addition, collagen has a well-established function in wound healing ${ }^{[22]}$. It is the main component which strengthens and supports extra cellular tissue ${ }^{[23]}$.

Sections in the skin of control rats showed few Caspase $3+v e$ immunostained cells in the superficial layers of the epidermis. In subgroups IIa and IIb, multiple +ve epidermal cells and multiple +ve cells extending down among the dermis were seen. The multiplicity of +ve cells was less apparent in subgroup IIb compared to subgroup IIa. A significant increase in the mean area\% of caspase 3 +ve cells was found in subgroups IIa and IIb compared to control group. The previous results were confirmed by Liu et $\mathrm{al}^{[24]}$, who reported that excessive oxidative stress alters the expression levels of apoptosis-related genes and triggers cell apoptosis through bcl-2, bax and caspase-3 signaling pathways. A recent study on wound healing estimated the rate of apoptosis by calculating the number of caspase- 3 positive cells over the total number of cells per high-powered field (20X) averaged over ten images ${ }^{[25]}$. Talebizadeh et al ${ }^{[26]}$ recorded that the changes in proteins expression regulate apoptosis and cellular recovery from damage. Caspase- 3 is one of the important proteins in the completion of apoptosis. It was added that information on active caspase- 3 will be useful both to understand the molecular biology of apoptosis and as a tool to study effects of damage to the epithelium such as oxidative insult. Jadhav et $a{ }^{[27]}$ documented that apoptosis was observed when cleaved-caspase-3 immunohistochemical staining was used. An inverse relation exists between caspase 3 expression and wound healing.

On the other hand, in a recent study performed on traumatic brain injury, degeneration, cellular loss, 
apoptosis, programmed cell death pathways were estimated by determination of caspase 3 expression and apoptosis-inducing factor (AIF). Unchanged expression of active caspase-3 at all post-injury time points was found, but there was increased expression of AIF on day $7^{[28]}$.

Sections in the skin of rats in subgroup IIa demonstrated some CD44+ve spindle cells in the epidermis and multiple +ve spindle cells in the dermis at the wound margins. While in subgroup IIb, some +ve spindle cells were found in the epidermis and dermis at the wound margins. These findings indicated decreased multiplicity of MSCs 3 weeks following wound induction, which can be related to more differentiation of MSCs into various skin components by progression of wound healing. In line with, it was mentioned that the epithelial-mesenchymal transition is one of the major factors that affect cell migration associated with wound healing and tissue regeneration ${ }^{[29]}$. This was referred to their ability to self-renew and their capability to differentiate into various cells ${ }^{[30]}$.

In subgroup IIIa (Non-diabetic wounded and GE treated subgroup sacrificed 2 weeks following wound induction and treatment), localized separation of epidermal edges, localized homogeneous acidophilic material in epidermis, discontinuity of granular and horny cell layers and occasional impacted keratin whorls, few vacuolated cells with nuclear margination and occasional localized vacuolated areas containing cellular debris were seen. Some hair follicles and related sebaceous glands were seen deep in the dermis. Separation of some C.T fibers was noticed. The previous results indicated more pronounced healing in response to local GE application. In accordance, there has been extensive scientific interest in the evaluation of the wound healing activity of medicinal plants ${ }^{[31]}$.

In subgroup IIIb (Non-diabetic wounded and GE treated subgroup sacrificed 3 weeks following wound induction and treatment), small detached parts of horny layer and focal separation of epidermal edges were found. Some follicles with related sebaceous glands, microfollicles and multiple deep follicles were detected in the dermis. Few epidermal cells demonstrated nuclear margination. Some of the deeper follicles showed the medulla and occasional ones demonstrated medulla, cortex of hair, internal root and external root sheaths. In confirmation, a significant increase in the mean distance between the epidermal edges was found in subgroup IIa compared to group III and in subgroup IIIa compared to subgroup IIIb. A significant increase was found in the mean thickness of the epidermis in subgroup IIa, compared to control and subgroup IIIb. Going with the previous results, it was mentioned that the enhanced healing effect induced by GE application can be related to the antioxidative role of allicin in stress-related cellular deficits. In addition, allicin can improve $\mathrm{T}$ cell subsets distribution through its immunomodulatory activity as proven by Gao et al. $\left[{ }^{33}\right]$.

The anti-inflammatory and antimicrobial effect of GE was also recorded in various studies. Wu et al..$^{[34]}$ confirmed the unique bactericidal effect of allicin on biofilms.

In subgroup IIIa some caspase3 +ve epidermal cells, while in subgroup IIIb, few +ve cells were found among the epidermis. A significant increase in the mean area $\%$ of caspase 3 +ve cells was reported in group II compared to control and group III. In agreement, Chen et $\mathrm{al}^{[35]}$ stated that caspase-3 is considered the main terminal cleavage enzyme in the apoptosis process and is responsible for the cleavage of the DNA repair enzyme, which is another hallmark of apoptosis. Allicin was proved to reduce the cleavage mechanism of caspase- 3 , consequently the role of allicin in preventing apoptosis was evidenced. On the other hand, Zhang et $a l^{[36]}$ reported that allicin increases apoptosis when used in high concentrations and for long durations.

Regarding CD44 immunostained sections, in subgroup IIIa multiple +ve spindle cells were demonstrated in the epidermis, dermis, hair follicles and hypodermis. In subgroup IIIb, few +ve spindle cells were seen in the epidermis and dermis, some $+v e$ spindle cells in hypodermis, in addition to multiple +ve spindle in hair follicles, A significant increase in the mean area\% of CD $44+$ ve cells was found in group III compared to group II. The previous data indicated increased MSCs marker expression. In line with, Park et $a l^{[37]}$ documented that SCs accelerate wound closure with an increased level of re-epithelialization, neovascularization, and regeneration of skin appendages. Concomitantly, Li et al ${ }^{[38]}$ proved that postnatal stem/progenitor cells hold great promise to enhance repair of damaged tissues. Many of these cells are retrieved from bone marrow or adipose tissue. They were described as fibroblastic cells, plastic-adherent and exhibit a surface marker profile positive for CD73, CD44, CD90. They were defined by the International Society for Cellular Therapy as MSCs.

\section{CONCLUSION}

In conclusion, GE constituting allicin as active constituent proved amelioration of the inflammatory, degenerative, necrotic and apoptotic changes developing at the wound site during healing in rats. This therapeutic effect was proved to be related to both caspase 3 pathway inactivation and MSC migration activation. This suggests GE or its active constituent, allicin to be applied in appropriate concentrations in 
the preparation of pharmaceutical products to be used safely on epithelial cells.

\section{CONFLICT OF INTEREST}

The authors have no conflicting financial interest.

\section{REFERENCES}

1. Breitkreutz D, Koxholt I, Thiemann K, Nischt R. Skin basement membrane: The foundation of epidermal integrity-BM functions and diverse roles of bridging molecules nidogen and perlecan. Biomed Res Int, 2013; 2013: 179784-179799.

2. Zimmermann AS, Morrison SD, Hu MS, Li S, Nauta A, Sorkin M, Meyer NP, Walmsley GG, Maan ZN, Chan DA, Gurtner GC, Giaccia AJ, Longaker MT. Epidermal or dermal specific knockout of PHD-2 enhances wound healing and minimizes ischemic injury. PLoS One, 2014; 9(4): e93373-93381.

3. Weinheimer-Haus EM, Judex S, Ennis WJ, Koh TJ. Low-intensity vibration improves angiogenesis and wound healing in diabetic mice. PLoS One, 2014; 9(3): e91355-91362.

4. Corral MJ, González-Sánchez E, Cuquerella M, Alunda JM. In vitro synergistic effect of amphotericin $\mathrm{B}$ and allicin on Leishmania donovani and $\mathrm{L}$ infantum. Antimicrob Agents Chemother, 2014; 58(3): 15961602.

5. Jiang H, Qu L, Dou R, Lu L, Bian S, Zhu W. Potential role of mesenchymal stem cells in alleviating intestinal ischemia/reperfusion impairment. PLoS One, 2013; 8(9): e74468-74477.

6. Ackermann M, Pabst AM, Houdek JP, Ziebart T, Konerding MA. Priming with proangiogenic growth factors and endothelial progenitor cells improves revascularization in linear diabetic wounds. Int J Mol Med, 2014; 33(4): 833-839.

7. Saifzadeh S, Tehrani A, Jalali FSS, Oroujzadeh R. Enhancing effect of aqeous garlic extract on wound healing in the dog: Clinical and histopathological studies. J Anim Vet Adv, 2006; 5(12): 1101-1104.

8. Ahmad A, Khan RM, Alkharfy KM. Effects of selected bioactive natural products on the vascular endothelium. J Cardiovasc Pharmacol, 2013; 62(2): 111-121.

9. Lee YS, Kwon ST, Kim JO, Choi ES. Experimental Study in a Rat Model with the Pathologic Correlation. Korean J Radiol, 2011; 12(1): 66-77.
10. Kiernan JA. Histological and Histochemical methods: Theory and practice, third edition, Arnold publisher, London, New York and New Delhi, 2001: 111-162.

11. Sun W, Su Q, Cao X, Shang B, Chen A, Yin H, Liu B. High Expression of Polo-Like Kinase 1 Is Associated with Early Development of Hepatocellular Carcinoma. Int J Genomics, 2014; 2014: 312130-312138.

12. Cai Y, Liu T, Fang F, Xiong C and Shen S (2015): Comparisons of Mouse Mesenchymal Stem Cells in Primary Adherent Culture of Compact Bone Fragments and Whole Bone Marrow. Stem Cells International, 2015: 708906-708913.

13. Emsley R, Dunn G, White IR. Mediation and moderation of treatment effects in randomized controlled trials of complex interventions. Stat Methods Med Res, 2010; 19(3): 237-270.

14. Vivas A, Fox JD, Baquerizo Nole KL, Maderal AD, Badiavas E, Cargill DI, Slade HB, Feldman SR, Kirsner RS. Cryo-Induced Thermal Wounds: A Human Acute Wound Model. J Drugs Dermatol, 2015; 14(7): 734-738.

15. Singer AJ, Dagum AB. Current management of acute cutaneous wounds. N Engl J Med, 2008; 359(10): 1037-1046.

16. Singh A, Halder S, Menon GR, Chumber S, Misra MC, Sharma LK, Srivastava A. Meta-analysis of randomized controlled trials on hydrocolloid occlusive dressings versus conventional gauze dressing in the healing of chronic wounds. Asian J Surg, 2004; 27(4): 326-332.

17. Irrera N, Bitto A, Pizzino G, Vaccaro M, Squadrito F, Galeano M, d'Alcontres FS, d'Alcontres FS, Buemi M, Minutoli L, Colonna MR, Altavilla D. Epoetin Alpha and Epoetin Zeta: A Comparative Study on Stimulation of Angiogenesis and Wound Repair in an Experimental Model of Burn Injury. Biomed Res Int, 2015; 2015: 968927-968935.

18. Woodley DT, Wysong A, DeClerck B, Chen M, Li W. Keratinocyte Migration and a Hypothetical New Role for Extracellular Heat Shock Protein 90 Alpha in Orchestrating Skin Wound Healing. Adv Wound Care (New Rochelle), 2015; 4(4): 203-212.

19. Ganesh K, Sinha M, Mathew-Steiner SS, Das A, Roy S, Sen CK. Chronic Wound Biofilm Model. Adv Wound Care (New Rochelle), 2015; 4(7): 382-388.

20. Buemi M, Lacquaniti A, Bolignano D, Maricchiolo G, Favaloro A, Buemi A, Grasso G, Donato V, Giorgianni G, Genovese L, Coppolino G, Sfacteria A. The 
erythropoietin and regenerative medicine: a lesson from fish.European Journal of Clinical Investigation, 2009; 39(11): 993-999.

21. Nurse P. long twentieth century of the cell cycle and beyond. Cell, 200; 100(1): 71-78.

22. Long KB, Burgwin CM, Huneke R, Artlett CM, Blankenhorn EP. Tight skin 2 mice exhibit delayed wound healing caused by increased elastic fibers in fibrotic skin. Adv Wound Care (New Rochelle), 2014; 3(9): 573-581.

23. El-Mesallamy HO, Diab MR, Hamdy NM, Dardir SM. Cell-based regenerative strategies for treatment of diabetic skin wounds, a comparative study between human umbilical cord blood-mononuclear cells and calves' blood haemodialysate. Plos One, 2014; 9(3): e89853-89862.

24. Liu Q, Si T, Xu X, Liang F, Wang L, Pan S. Electromagnetic radiation at $900 \mathrm{MHz}$ induces sperm apoptosis through bcl-2, bax and caspase-3 signaling pathways in rats. Reproductive Health, 2015; 12: 6573.

25. Balaji S, King A, Marsh E, LeSaint M, Bhattacharya SS, Han N, Dhamija Y, Ranjan R, Le LD, Bollyky $\mathrm{pL}$, Crombleholme TM, Keswani SG. The Role of Interleukin-10 and Hyaluronan in Murine Fetal Fibroblast Function In Vitro: Implications for Recapitulating Fetal Regenerative Wound Healing. PLoS One, 2015; 10(5): e0124302-0124319.

26. Talebizadeh N, Yu Z, Kronschläger M, Söderberg P. Modelling the Time Evolution of Active Caspase-3 Protein in the Rat Lens after In Vivo Exposure to Ultraviolet Radiation-B. PLoS One, 2014; 9(9): e106926-106930.

27. Jadhav SS, Meeks CJ, Mordwinkin NM, Espinoza TB, Louie SG, diZerega GS, Rodgers KE. Effect of combined radiation injury on cell death and inflammation in skin. Apoptosis, 2015; 20(7): 892906.

28. Dolenec P, Pilipović K, Rajič J, Župan G. Temporal pattern of neurodegeneration, programmed cell death, and neuroplastic responses in the thalamus after lateral fluid percussion brain injury in the rat. J Neuropathol Exp Neurol, 2015; 74(6): 512-526.

29. Ikenouchi J, Matsuda M, Furuse M, Tsukita S. Regulation of tight junctions during the epithelium- mesenchyme transition: direct repression of the gene expression of claudins/occludin by Snail. J Cell Sci, 2003; 116(10): 1959-1967.

30. Huang JI, Zuk PA Jones NF, Zhu M, Lorenz HP, Hedrick MH, Benhaim P. Chondrogenic potential of multipotential cells from human adipose tissue. Plast Reconstr Surg, 2004; 113(2): 585-594.

31. Balbani AP, Silva DH, Montovani JC. Patents of drugs extracted from Brazilian medicinal plants. Expert Opin Ther Pat, 2009; 19(4): 461-473.

32. Zhu YF, Li XH, Yuan ZP, Li CY, Tian RB, Jia W, Xiao ZP. Neuropharmacology and analgesia Allicin improves endoplasmic reticulum stress-related cognitive deficits via PERK/Nrf2 antioxidative signaling pathway. Eur J Pharmacol, 2015; 762: 239246.

33. Gao XY, Geng XJ, Zhai WL, Zhang XW, We Y, Hou GJ. Effect of combined treatment with cyclophosphamidum and allicin on neuroblastomabearing mice. Asian Pac J Trop Med, 2015; 8(2): 137 141.

34. Wu X, Santos RR, Fink-Gremmels J. Analyzing the antibacterial effects of food ingredients: model experiments with allicin and garlic extracts on biofilm formation and viability of Staphylococcus epidermidis Food Sci Nutr, 2015; 3(2): 158-168.

35. Chen S, Tang Y, Qian Y, Chen R, Zhang L, Wo L, Chai H. Allicin prevents $\mathrm{H} \square \mathrm{O} \square$-induced apoptosis of HUVECs by inhibiting an oxidative stress pathway. BMC Complement Altern Med, 2014; 14: 321-328.

36. Zhang X, Zhu Y, Duan W, Feng C, He X. Allicin induces apoptosis of the MGC-803 human gastric carcinoma cell line through the p38 mitogen-activated protein kinase/caspase-3 signaling pathway. Mol Med Rep, 2015; 11(4): 2755-2760.

37. Park IS, Chung PS, Ahn JC. Enhancement of Ischemic Wound Healing by Spheroid Grafting of Human Adipose-Derived Stem Cells Treated with Low-Level Light Irradiation. PLoS One, 2015; 10(6): e01227760122791 .

38. Li S, Huang KJ, Wu JC, Hu MS, Sanyal M, Hu M, Longaker MT, Lorenz HP. Peripheral blood-derived mesenchymal stem cells: candidate cells responsible for healing critical-sized calvarial bone defects. Stem Cells Transl Med, 2015; 4(4): 359-368. 
الملخص العربى

\section{دراسة هستولوجية علي أثر مستخلص الثوم على الجرح المحدث فى ذكر الجرذ: الاور المحتمل للخلايا الجذعية الداخلية \\ محمود رضاث لمباء ابراهيم عبدالفتاح**، داليا حسين حلمى، \\ أسماء محمود مصطفى \# ليلى أحمد راشد}

\section{اقسام الجراحة العامة جامعة مصر للعلوم و التكنولوجيا*، الههتولوجيا كلية الطب جامعة}

\section{القاهرة** و جامعة بنى سويف\#، الكيمياء الحيوية كلية الطب جامعة القاهرة}

الخلفية و الأهداف: الجروح المزمنة تمثل مشكلة صحية كبيرة. هناك حاجة لطرق علاجية حديثة لالتئام الجروح. يعد الثوم (اليام ساتيفم) مضادا للاكسدة و مضادا للبكتيريا و مضادا للكوليسترول. يهدف العمل الحالى لفحص التأثير العلاجى المحتمل لمستخلص الثوم على الجرح المحدث فى ذكر الجرذ. تم تحديد الدور المحتمل للخلايا الجذعية الداخلية. الطرق: ستة و عشرون من ذكور الجرذان البالغة تم تقسيمهم الى: مجموعة \ـ ( مجموعة ضابطة): ستة جرذان لم يتعرضوا

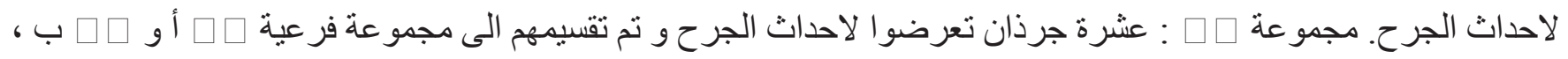

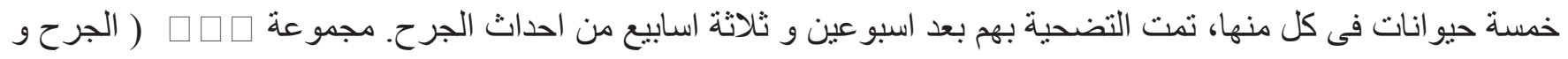

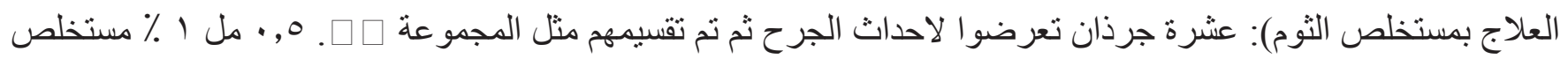
الثوم تم وضعها فى المكان بعد احداث الجرح. قطاعات الجلا (تشمل الجرح و منطقة سليمة محيطة به) تعرضوا لدراسات هستولوجية و هستوكيميائية مناعية و قياسيةو احصائية. النتائج: وجد فى الجرذان المجروحة تغيرات مورفولوجية تدل على الالتهاب و التنكس. مع استخدام مستخلص الثوم تراجعت تللك التغير ات بشكل لافت للنظر . تر اجع الموت المبرمج للخلايا تم تاكيده بالصباغة المناعية ل كاسبيز ب و تنشيط الخلايا الجذعية تم اثباته بالصباغة المناعية ل سى دى ع ؛. الخلاصة: التأثنر العلاجى لمستخلص الثوم ثبت انه يتعلق بكل من تعطيل مسار كاسبيز ب و تنشيط هجرة الخلايا الجذعية الوسيطة. يقترح وضع مستخلص الثوم بتركيز ات مناسبة فى تحضير المنتجات الصيدلية ليستخدم بامان على الخلايا الطلائية فى رعاية الجروح. 